\title{
IN HALTS VERZEICHNIS
}

Spalte

Abkürzungen und Sigel . . . . . . . . . VII

\section{Allgemeines}

A. Bibliographien und allgemeine Forschungsberichte . . . . . . .

B. Enzyklopädie und Methodologie. Ausgrabungswesen, Denkmalpflege . 4

C. Geschichte der Archäologie. Biographien. Nekrologe . . . . . . . . 9

D. Zeitschriften. Fest- und Gelegenheitsschriften. Sammelwerke . . . . . 2 I

E. Instituts- und Tagungsberichte . . 29

II. Ortliche Ubersicht

A. Archäologische Ortskunde

I. Allgemeines . . . . . . . . 34

2. Orient und Ägypten . . . . . . 35

3. Griechenland. Donauländer.

Kleinasien . . . . . . . $5^{\mathrm{I}}$

4. Italien . . . . . . . . . 80

5. Nordafrika . . . . . . . . 99

6. Gallien .. . . . . . . . . 102

7. Helvetien . . . . . . . . r Io

8. Iberien . . . . . . . . . . II2

9. Britannien. Skandinavien . . . . II5

Io. Germanien . . . . . . . . . I I9

I I. Sowjetunion. Polen. Schwarzmeergebiet . . . . . . . . . 123

B. Museen und Ausstellungen . . . . . I24

III. Sachliche Ubersicht

A. Allgemeine Kunstgeschichte und Geschichte. Nachleben der Antike

I. Allgemeines . . . . . . . . . I33

2. Orient und Agypten . . . . . . $1_{36} 6$

3. Griechenland und Rom: Allgemeines. Vorgeschichte . . . . . I5I

4. Griechische Geschichte . . . . I57

5. Griechische Kunst . . . . . I65

6. Römische und provinzialrömische Geschichte . . . . . . . 167

7. Römische und provinzialrömische Kunst . . . . . . . . . 185

8. Spätantike. Urchristentum. Byzanz. Nachleben . . . . . . . I87

B. Architektur

I. Allgemeines . . . . . . . . . 200

2. Orient und Ägypten . . . . . . 200

3. Griechenland und Rom . . . . 203

C. Plastik

I. Allgemeines. Orient und Agypten 212

2. Griechenland und Rom . . . 2 2 I5
D. Malerei und Zeichnung. Mosaiken

I. Allgemeines. Orient und Ägypten 236

2. Griechenland und Rom . . . . 237

E. Kunstgewerbe und Kleinkunst

I. Allgemeines. Orient und Ägypten 250

2. Griechenland und Rom . . . . 255

F. Numismatik und Metrologie

I. Numismatik . . . . . . . . 277

2. Metrologie . . . . . . . . 293

G. Epigraphik

r. Allgemeines . . . . . . . . . 294

2. Nicht griechisch-römische Inschriften . . . . . . . . . . 295

3. Griechische Inschriften . . . . 298

4. Italische und römische Inschriften 306

H. Religion, Mythos, Kult

I. Allgemeine und vergleichende Religionswissenschaft . . . . 317

2. Orient, Agypten, Israel . . . . 318

3. Griechenland, Rom, römische Provinzen . . . . . . . . 326

I. Ikonographie

I. Allgemeines. Orient und Ägypten 338

2. Griechenland und Rom . . . 338

K. Kulturgeschichte. Offentliches und privates Leben

I. Allgemeines. Staatsverwaltung und Politik . . . . . . . . . . . 342

2. Kriegswesen. Heer und Flotte. Seefahrt . . . . . . . . 359

3. Wirtschaft und Verkehr . . . . 364

4. Soziale Verhältnisse. Bevölkerungsklassen. Berufsleben . . . . . 369

5. Familie. Ehe. Bestattung und Verbrennung . . . . . . . . . 374

6. Feste. Spiele. Tanz. Sport . . . 376

7. Musik . . . . . . . . $37^{8}$

8. Theater . . . . . . . . . 380

9. Buch und Bibliotheken. Schriftwesen. Kalender. Bildung . . . 380

ro. Kleidung. Tracht. Ernährung und Körperpflege . . . . . . . $3^{85}$

I I. Medizin. Naturwissenschaften. Technik. Bergbau . . . . . 386 